\title{
Professional Integrity within the Structure of Professional Activity: Psychological and Pedagogical Formation Basis
}

\author{
Nataliya Petrovna Gavrilyuk ${ }^{1 *}$, Yana Vladimirovna Kryucheva ${ }^{1}$, Svetlana Nikolaevna Semenkova ${ }^{2}$ \\ ${ }^{I}$ Federal State Budgetary Educational Institution of Higher Education «Industrial University of Tyumen», Volodarskogo St., 38, Tyumen, \\ 625000, Russia \\ ${ }^{2}$ Federal State Budgetary Educational Institution of Higher Education «Northern Trans-Ural State Agricultural University», Respubliki \\ St., 7, Tyumen, 625003, Russia \\ *Corresponding author E-mail: gavrilyuk.n.p@mail.ru
}

\begin{abstract}
The article covers the issues related to the process of training students for professional activity. The authors introduce a new term "professional integrity". This term is presented by three interrelated structural components: cognitive, communicative, and behavioral. The psychological and pedagogical basis of professional activity is theoretically justified. Diagnostic tools for the problematic area of professional activity are verified empirically. The sources of difficulties and problems faced by a person in professional activity are found out. The authors identify a correlation among the sources of difficulties of a person in the important life spheres. Psychological and pedagogical recommendations on solving problems related to the formation of professional activity at higher education institutions are developed. The findings can be attractive for teachers, psychologists, postgraduate students interested in problems of starting professional activity.
\end{abstract}

Keywords: Competence; Professional activity; Professional integrity.

\section{Introduction}

The modern socio-economic development of the country imposes new content- and organization-related requirements on professional activity, that is, on students training in the higher education system.

Current-day graduates are to be competitive, mobile, and adaptive to new working environment within the shortest possible time, improve their qualification continuously, and tend to professional development and self-realization.

The topicality of the research is proved by studies of modern scientists, who focus on one or another component of professional activity while discussing the training of professionals.

Abulkhanova-Slavskaya, Klimov and Novikov study professional adaptability as a tool, effective introduction into professional activity $[1,2]$. Other authors talk about professional mobility. Thus, Dvoretskaya considers this term as "a personality adaptation mechanism enabling a person to manage the resources of subjectivity and professional behavior" [3].

Goryunova defines mobility "first, as a personal quality ensuring the internal mechanism of personal growth; second, personal activity determined by events that change the environment resulting in the self-realization of a person in his or her profession and life; third, a process of transforming by a person of him/herself and his or her professional and living environment" [4].

Dyachenko, \& Kandybovich underline that basis for professional mobility is formed, first of all, by a high level of general professional knowledge, command of general professional methods and ability to apply them in the profession effectively [5, $6]$.
In studies by Zeer, Bodrov and Kudryavtseva, pride of place goes to the professional becoming of personality. For example, Zeer points out the following stages of professional becoming: amorphous option, option, professional training, professional adaptation, primary professionalization, secondary professionalization, professional skills [7].

So, we have a contradiction between the public demand for confident workers with an active professional position and the insufficient development of the problematic area of professional activity in the context of higher education.

Goal of the research is to justify theoretically and to develop practically the psychological and pedagogical basis for the formation of professional activity.

Objectives of the research are as follows: 1) to set definitions of professional activity; 2) to justify theoretically the psychological and pedagogical basis of professional activity; 3) to test empirically the diagnostic tools of the problematic area of professional activity; 4) to develop psychological and pedagogical recommendations on solving problems related to the formation of professional activity at higher education institutions.

According to the first objective, we set the definitions of the studied issue.

Following Petrovskiy's theory, a person has three stages of development [8].

1) The adaptation stage - mastering moral, production norms in a group, means and methods of activity peculiar to its members.

Petrovskiy says that if a person cannot overcome difficulties of the adaptation stage, he or she acquires qualities of a dependant, passive, timid person, who is not confident in him/herself and his/her abilities - a negative scenario for this stage. 
2) The individualization stage - if a person develops positively at this stage, stable demonstration and assertion of his/her individuality is formed.

A negative scenario at the second stage promotes negation, aggression, suspicion, inadequate self-appraisal.

3) The integration stage is focused on the acceptance of a person by a group promoting the formation of collectivism as a stable personal quality.

Otherwise, we can see the disintegration of a person in a group, as a person is pushed out by a group or isolated in a group, which cannot be left.

Overcoming the difficulties of the integration process in different important social groups is very important for personal growth at each developmental stage, says Petrovskiy [8].

During life, a person enters different groups and can be accepted in one group and ignored in the other one. Thus, successful or unsuccessful adaptation, individualization and integration repeat many times resulting in the formation of a stable structure of personality.

If the tasks of any stage are not solved, a negative scenario of development of personality will follow him or her until he or she solves tasks of the stage.

If a person does not solve the integration task in a previous developmental period, he or she will have difficulties with adaptation in the next developmental period.

Conducting professional activity in a work group, a person demonstrates adaptation, individualization and integration skills, formed at previous developmental stages.

Hence, the author's opinion in the frames of studying professional activity is determined by a new term - "professional integrity", which provides for a vector of active professional position of a person in a significant social group (a work collective in the course of professional activity), collectivism as a personal quality. Thus, by professional integrity we shall basically understand a complex of internal resources of a person required for successful mastering of a new professional role, formulation of an individual style of activity promoting the active transformation of the professional environment.

According to the second objective, we present the theoretical justification and development of the psychological and pedagogical basis of the professional activity of a modern worker. The competency-building approach, which will be considered as a theoretical basis of the research, is a modern approach to education in the context of education modernization $[9,10]$.

This approach enables both to master knowledge needed and to acquire skills, to develop personal qualities most in demand nowadays ensuring the successful fulfillment of production tasks. Competences are a complex of interrelated personal qualities (knowledge, skills, and work methods) set towards specific objects and processes and required for a quality productive activity [11].

Zimnyaya thinks that competences are to involve such characteristics as: a) readiness to show competences (that is, the motivation aspect); b) knowledge of the competence content (that is, the cognitive aspect); c) experience in showing competences in different standard and nonstandard situations (that is, the behavioral aspect); d) attitude to the competence content and the object of its application (the axiological aspect); e) emotional and volitional regulation of the competence demonstration process and result [12].

Taking into account the views of the above-mentioned authors, from a perspective of the competence approach, professional integrity as a personal competence may be presented by three structural components corresponding to the target competences: 1) cognitive (to know); 2) communicative (to be able); 3) behavioral (to master).

The formation of professional integrity is ensured by the interrelation of its three components.

According to the empirical objective of the research, study of the problematic area of professional activity, we were interested in the source of difficulties and problems, which could be faced by a person during professional activity.

Part-time students (100 persons) at the age of 25-40 years, corresponding to the emerging adulthood period, were tested. The basis of the research was Tyumen Industrial University. The period was November-December 2016 to January-February 2017.

Based on Petrovskiy, we think that the sources of difficulties of a person in important groups depend on his or her age. So, difficulties during the emerging adulthood period are defined not only in the professional sphere, but also in the married life, relations with relatives, in the social sphere, where a person demonstrates adaptation, individualization and integration skills formed at previous developmental stages.

\section{Methods}

Thus, for the empirical study we have chosen the method "I. Koler's questionnaire to study the patient's satisfaction with his or her functioning in different spheres" [13]

In this method, a respondent was to assess the sources of difficulties in four spheres: the professional sphere, married life, relations with relatives, and the social sphere. The offered statements were to be assessed in compliance with their degree from "quite true" to "quite wrong". The results were evaluated by a five-point scale, where the highest point was assigned to "quite true". In general, this method provides rather for a qualitative analysis of the results with regard to specified problematic areas in four spheres.

In this article, we offer the authors' modified variant of processing the findings by Spearman's rank correlation method enabling to determine the strength and direction of correlation between two features or two feature profiles (hierarchies) [14].

So, after defining the number of points on each question in each four spheres of life (the professional sphere, married life, relations with relatives, the social sphere), we ranked the sources of difficulties based on their degree of influence on a person in each sphere. The maximum point was set in each sphere, where it was rated "1".

\section{Results}

In the professional sphere, the maximum number of points was set to the question "I am stopped by the daily routine of my work". This source of difficulties was rated "1".

Consequently, such source of difficulties as "I have difficulties due to overworking and insufficient appreciation of my work" was ranked "2", because this question got 1 point less.

In the married life sphere, the question "I have difficulties due to differences in temperament and character" got a maximum number of points. This source of difficulties was ranked "1".

In the sphere of relations with relatives, the question "I have disagreements with my father" got a maximum number of points.

In the social sphere, the question "I think that lack of social activities is my drawback" got a maximum number of points.

Then, we conducted a correlation analysis of the sources of difficulties in the professional sphere with the difficulties in the rest three spheres of resulting hierarchies - in the married life, relations with relatives, and the social sphere.

Thus, the obtained empirical data were subject to the statistical analysis in order to determine a ratio and direction of correlation between two spheres: professional and married life, professional and relations with relatives, professional and social.

The interpretation of the obtained results can be built in the correlation search logic: among the sources of personal difficulties in significant spheres, correspondingly, among competences in overcoming difficulties in different spheres of life. Thus, if two features of personal attitude to the sources of difficulties are in correlation (the result goes to the zone of 
certainty on "the significance axis", then a correlation of relevant competences in overcoming difficulties in these spheres of life is possible, otherwise we can speak about lack of interrelation of competences in overcoming difficulties in these spheres of life.

The choice of this method of finding the correlation dependence was determined by the following condition: we have studied two features in the same group of testees.

Spearman's rank correlation coefficient was calculated by the formula:

$$
r_{S} e m p .=1-\frac{6 \times \sum\left(d^{2}\right)}{n \times\left(n^{2}-1\right)}
$$

Where, $\mathrm{d}$ was the difference between ranks on two variables for each $n$ (the number of questions in the questionnaire subject to processing with regard to each sphere of life); $n$ was the number of ranked values $(n=11)$

We compared the obtained empirical value to critical values:

$r_{S} c r .=\left\{\begin{array}{c}0.61(p \leq 0.05) \\ 0.76(p \leq 0.001)\end{array}\right\}$

The result was put together with critical values on the "significance axis".

There is no correlation, if:

$r_{S} e m p . \leq r_{S} c r$.

Below are the research results of correlation of the sources of difficulties in the professional sphere and married life.

$r_{S}$ emp. $=1-\frac{6 \times \sum\left(d^{2}\right)}{n \times\left(n^{2}-1\right)}=1-\frac{6 \times 172.25}{11 \times\left(11^{2}-1\right)}=1-\frac{1033}{1320}=1-1.78=0.22$

Conclusion: the empirical value 0.22 means that there is no correlation between the sources of difficulties in the professional sphere and married life.

Below are the research results of correlation of the sources of difficulties in the professional sphere and relations with relatives.

$r_{S}$ emp. $=1-\frac{6 \times \sum\left(d^{2}\right)}{n \times\left(n^{2}-1\right)}=1-\frac{6 \times 47}{11 \times\left(11^{2}-1\right)}=1-\frac{282}{1320}=1-0.21=0.79$

Conclusion: the empirical value 0.79 means that there is a correlation between sources of difficulties in the professional sphere and relations with relatives.

Below are the research results of correlation of the sources of difficulties in the professional and social spheres.

$r_{S} e m p \cdot=1-\frac{6 \times \sum\left(d^{2}\right)}{n \times\left(n^{2}-1\right)}=1-\frac{6 \times 252.5}{11 \times\left(11^{2}-1\right)}=1-\frac{1515}{1320}=1-1.14=-0.14$

Conclusion: the empirical value -0.14 means that there is no correlation between the sources of difficulties in the professional and social spheres.

\section{Results and Discussion}

Thus, based on the results of processing I. Koler's questionnaire by Spearman's rank correlation method, it was found out as follows: the correlation between the sources of difficulties of a person in the professional sphere and relations with relatives
(Figure 1); no correlation between sources of difficulties of a person in the professional sphere with married life and social spheres.

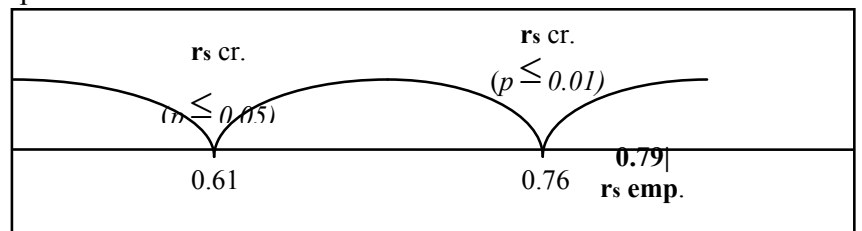

Fig. 1: Correlation between the sources of difficulties in the professional sphere and relations with relatives

Also, it should be noted that this processing does not exhaust the possibilities for a future comprehensive analysis of these research results.

According to the fourth objective, we present psychological and pedagogical recommendations on solving problems related to the formation of professional activity at higher education institutions. We think that professional integrity as a required competence of professional activity can be formed within the frame of psychological sciences.

Thus, for example, a course Psychology of Business Dialogue is focused on the collaborative experience of people under working conditions. It assists students in developing such personal qualities as business activity, responsibility, stress resistance, self-control, behavioral flexibility, etc.; promotes the development of the need for self-realization.

The cognitive component includes the basic terms of Psychology of Business Dialogue. Students should know: key components of mental organization of a person, forms of business communication in a team, rules and principles of modern business custom, features of social perception, key elements of business communication, features of nonverbal behavior and nonverbal means in business communication, aspects of speech as means of verbal communication, key concepts of social interaction, key characteristics of a working group as a social-psychological community, social-psychological phenomena of social increment, informal structure of a working group, its formation and function features, key management styles and their application conditions, strategies of interaction under the conflict.

The communicative component includes personal abilities to perform an effective social interaction. So, a student should be able to: compare the psychological features of a person with his or her behavior to optimize business communication, use feedback effectively within the communication process, understand body language and use it in the course of communication effectively, use oral and written language as communicative means, make contacts with the company, analyze own activities and interpersonal relations in a group to improve them, create an image of a corporation and a person, make decisions independently, show initiative, build an individual professional development path.

The behavioral component includes the knowledge-use experience an ability to perform production tasks in a quick, professional and quality manner. A student should study: communicative tools and methods of interaction in a working group, psychotechnics of communication behavior in the context of a conflict, personal and professional improvement skills, self-realization skills.

Taking into account empirical findings, it is practical to complete competences from the professional sphere with competences from the sphere of relations with relatives. It requires additional research and practice studies.

Thus, the goal of the research has been achieved, as we present the theoretical justification and practical development of psychological and pedagogical basis of forming the professional activity. 


\section{Conclusions}

Conclusions according to the set objectives are as follows:

1) the authors relate the definitions within the frame of studying professional activity to Petrovskiy's theory; they determine and introduce a new term - "professional integrity";

2) the theoretical justification and development of the psychological and pedagogical basis of professional activity of a modern worker are presented within the frame of the competence approach; "professional integrity" is presented by relevant components - competences;

3 ) the study of the problematic area of professional activity is connected with the search for correlation of different spheres of life at a specific developmental stage (middle age); the authors present a modified variant of processing the results of the methods "I. Koler's questionnaire to study the patient's satisfaction with his or her functioning in different spheres" by Spearman's rank correlation method; the authors identify the correlation between the professional sphere and relations with relatives;

4) psychological and pedagogical recommendations on solving problems related to the formation of professional activity at higher education institutions are presented within the frame of psychological sciences according to three competences of professional integrity (cognitive, communicative, and behavioral).

\section{References}

[1] Abulkhanova-Slavskaya KA (1980), Deyatelnost i psikhologiya lichnosti [Activity and Psychology of Personality]. Moscow: Nauka.

[2] Klimov EA (1996), Psikhologiya professionala: Ucheb. posobie [Psychology of a Professional: Study Guide]. Moscow; Voronezh: Institute of Practical Psychology.

[3] Dvoretskaya YY (2007), Psikhologiya professionalnoi mobilnosti lichnosti: Avtoreferat diss. kand. psikhol. nauk [Psychology of Professional Mobility of Personality (Ph.D. Thesis Abstract)]. Krasnodar.

[4] Goryunova LV (2006), Professionalnaya mobilnost spetsialista kak problema razvivayushchegosya obrazovaniya Rossii: Avtoreferat dis. ... doktora pedagogicheskikh nauk [Occupational Mobility of a Specialist as a Problem of Developing Education in Russia (Doctoral Thesis Abstract)]. Rostov-on-Don.

[5] Dyachenko MI \& Kandybovich LA (2004), Psikhologicheskii slovar-spravochnik [Psychological Glossary]. Moscow: Kharvest.

[6] Yaroshevskiy MG (1996), Istoriya psikhologii ot antichnosti do serediny $X X v$. Ucheb. Posobie [History of Psychology from the Ancient World till the Middle of the 20th Century. Study Guide]. Moscow.

[7] Zeer EF (2013), Psikhologiya professionalnogo obrazovaniya: uchebnik dlya stud. uchrezhdenii vyssh. prof. obrazovaniva [Psychology of Vocational Education: Textbook for Postsecondary Institutions]. Moscow: Academia.

[8] Petrovskiy AV (1982), Lichnost. Deyatelnost. Kollektiv [Personality. Activity. Collective]. Moscow: Politizdat.

[9] Gavrilyuk NP (2016), Osobennosti deyatelnosti pedagogicheskogo rabotnika $\mathrm{v}$ usloviyakh modernizatsii rossiiskogo obrazovaniya [Specifics of a Teacher's Activity within Modernization of Russian Education]. Uspekhi sovremennoi nauki 12(12), 141-143.

[10] Kryucheva YaV \& Gavrilyuk NP (2016), Deyatelnostnyi i kompetentnostnyi podkhody $\mathrm{v}$ obrazovanii: uspeshnost $\mathrm{v}$ integratsii [Activity and Competency-Based Approaches in Education: Success in Integration]. Professionalnoe obrazovanie $v$ sovremennom mire 3, 421-428.

[11] Khutorskoy AV (2003), Klyuchevye kompetentsii kak komponent lichnostno-orientirovannogo obrazovaniya [Key Competences as a Component of the Person-Centered Education]. Narodnoe obrazovanie, 2, 58-64.

[12] Zimnyaya IA (2003), Klyuchevye kompetentsii - novaya paradigma rezultata obrazovaniya [Key Competences - a New Paradigm of Education Results]. Vysshee obrazovanie segodnya 5, $34-42$.

[13] Sidorenko EV (2006), Metody matematicheskoi obrabotki v psikhologii [Mathematic Treatment Methods in Psychology]. St. Petersburg: Rech.
[14] Sidorenko EV (2006), Metody matematicheskoi obrabotki v psikhologii [Mathematic Treatment Methods in Psychology]. St. Petersburg: Rech. 